\title{
Effect of oleic-linoleic acid and $\beta$-sitosterol to freezing extender of bulls and stallions semen
}

\section{Efeito da adição de ácido oleico-linoleico e $\beta$-sitosterol ao diluente de congelação do sêmen de touros e garanhões}

\author{
Breno Fernandes Barreto Sampaio ${ }^{1}$; Érika Saltiva Cruz Bender ${ }^{1}$; \\ Eliane Vianna da Costa-e-Silva²; Carmem Estefânia Serra Neto Zúccari ${ }^{2 *}$
}

\begin{abstract}
Addition of polyunsaturated fatty acids and/or cholesterol to a freezing diluent can modify the sperm plasma membrane composition, influencing its behavior during cryopreservation, thus, favoring seminal cryoresistance. The present study aimed to evaluate the effects of the addition of oleiclinoleic acid, (OLA); $\beta$-sitosterol ( $\beta$-sit), a plant analog of cholesterol; and OLA $+\beta$-sit in combination to a freezing diluent, on the cryopreservation bull and stallion semen. The following variables were analyzed: motility/vigor, plasma and acrosomal membrane integrity (by Trypan Blue/Giemsa staining), mitochondrial activity (by DAB staining), and lipid peroxidation (by a TBARS assays). The lipids were added according to experimental treatments: $\mathrm{C}$ - control group, A1 and A2 - OLA at concentrations of $37 \mu \mathrm{M}$ and $74 \mu \mathrm{M}, \mathrm{B} 1$ and $\mathrm{B} 2-\beta$-sit at concentrations of $1 \mu \mathrm{g} \mathrm{mL^{-1 }}$ and $2 \mu \mathrm{g} \mathrm{mL} \mathrm{L}^{-1} ; \mathrm{AB} 1$ and $\mathrm{AB} 2-\mathrm{OLA}$ $37 \mu \mathrm{M}+\beta$-sit $1 \mu \mathrm{g} \mathrm{mL}^{-1}$ and OLA $74 \mu \mathrm{M}+\beta$-sit $2 \mu \mathrm{g} \mathrm{mL}^{-1}$, respectively. The study was divided into three experiments; in Experiment 1, the concentrations of the groups A1, B1, and AB1 were evaluated, whereas in Experiment 2 the concentrations of the groups A2, B2, and AB2 were analyzed, both experiments were performed with bull semen. We conducted Experiment 3 using equine semen with the addition of lipids at all of the concentrations described. Data were subjected to analysis of variance, using the GLM procedure of SAS, with treatment means compared by Duncan test considering 5\% significance. These variables differed significantly after thawing the semen post-collection. However, there was no significant difference between treatments when variables were compared within the same time point, except for Experiment 2, where there was a decrease in motility and vigor decrease postthaw in the groups following $\beta$-sit addition $(\mathrm{C}-51.0 \pm 13.7 \% / 2.9 \pm 0.4 ; \mathrm{B} 2-35.8 \pm 15.8 \% / 2.3 \pm 0.6$; $\mathrm{AB} 2-38.5 \pm 16.6 \% / 2.5 \pm 0.5$, respectively; $p<0.05)$. In conclusion, the tested concentrations of these lipids did not confer greater cryoresistance to the spermatozoa, and were not effective in preserving the structural integrity of plasma and acrosomal membranes after thawing. Furthermore, there was no change in the mitochondrial activity and lipid peroxidation due to lipids addition.
\end{abstract}

Key words: Cholesterol, cryopreservation, PUFAs, spermatozoa

\section{Resumo}

A adição de ácidos graxos poli-insaturados e/ou colesterol ao diluidor pode modificar a composição da membrana plasmática do espermatozoide, influenciando seu comportamento frente à criopreservação e favorecendo, assim, a crioresistência seminal. O presente trabalho teve como objetivo avaliar o efeito da adição do ácido oleico-linoleico (AOL), $\beta$-sitosterol ( $\beta$-sit), um análogo vegetal do colesterol, e da

1 Discentes do Programa de Pós-Graduação em Ciência Animal, Faculdade de Medicina Veterinária e Zootecnia, Universidade Federal de Mato Grosso do Sul, FAMEZ/UFMS, Campo Grande, MS, Brasil. E-mail: br_sampaio@hotmail.com; erikabender. vet@gmail.com

2 Prof $^{\text {as }}$ Dr $^{\text {as }}$, FAMEZ/UFMS, Campo Grande, MS, Brasil. E-mail: eliane.silva@ufms.br; carmem.zuccari@ufms.br Author for correspondence 
associação $\mathrm{AOL}+\beta$-sit, ao diluente de congelação de sêmen bovino e equino. As variáveis analisadas foram motilidade/ vigor, integridade das membranas plasmática e acrossomais (Trypan Blue/Giemsa), atividade mitocondrial (DAB) e nível de peroxidação lipídica (TBARS). Os lipídios foram adicionados de acordo com os tratamentos experimentais: $\mathrm{C}$ - grupo controle; A1 e A2 - AOL nas concentrações de $37 \mu \mathrm{M}$ e $74 \mu \mathrm{M}$; B1 e B2 - $\beta$-sit nas concentrações de $1 \mu \mathrm{g} \mathrm{ml}^{-1}$ e $2 \mu \mathrm{g} \mathrm{ml}^{-1}$; AB1 e AB2 - AOL $37 \mu \mathrm{M}+$ $\beta$-sit $1 \mu \mathrm{g} \mathrm{ml}^{-1}$ e AOL $74 \mu \mathrm{M}+\beta$-sit $2 \mu \mathrm{g} \mathrm{ml}^{-1}$, respectivamente. $\mathrm{O}$ trabalho consistiu de três experimentos, sendo que o Experimento 1 testou as concentrações dos grupos A1, B1 e AB1, e o Experimento 2 as concentrações dos grupos A2, B2 e AB2, ambos utilizando sêmen de touro. Para o Experimento 3 utilizou-se sêmen equino, sendo a adição dos lipídios feita em todas a concentrações descritas. Os dados foram submetidos à análise de variância, através do procedimento GLM do SAS, sendo as médias dos tratamentos comparadas pelo teste de Duncan em nível de 5\% de significância. Os valores das variáveis avaliadas pós-descongelação diferiram significativamente daqueles obtidos pós-colheita, porém não foi observada diferença significativa entre os tratamentos quando as variáveis foram comparadas dentro do mesmo momento, exceto no Experimento 2, em que os valores de motilidade / vigor pós-descongelação nos grupos acrescidos do $\beta$-sit foram menores que os do controle $(\mathrm{C}-51,0 \pm 13,7 \% / 2,9 \pm 0,4$; $\mathrm{B} 2-$ $35,8 \pm 15,8 \% / 2,3 \pm 0,6 ; \mathrm{AB} 2-38,5 \pm 16,6 \% / 2,5 \pm 0,5$, respectivamente; $\mathrm{p}<0,05)$. Conclui-se que nas concentrações testadas, os lipídios não conferiram maior crioresistência ao espermatozoide, portanto não foram efetivos em preservar a integridade estrutural das membranas plasmática e acrossomais pósdescongelação. Da mesma forma, não houve alteração da atividade mitocondrial nem da peroxidação lipídica frente à adição dos lipídios.

Palavras-chave: Colesterol, criopreservação, espermatozóide, PUFAs

\section{Introduction}

Cryopreservation of sperm cells is beneficial for the genetic improvement of cattle because it permits the use of genetically superior animals and the storage and transportation of sperm cells over long distances. However, the freeze-thawing process can damage the plasma membrane, resulting from thermal, osmotic, and toxic stress (GIRAUD et al., 2000). These conditions can result in up to $50 \%$ reduction in the viability of spermatozoa (WATSON, 2000).

The degree of fluidity of spermatic membranes has an effect on spermatozoa behavior during cryopreservation. More rigid membranes are susceptible to changes in permeability and become more sensitive to osmotic stress, whereas more flexible membranes make spermatozoa more resistant to freezing. The degree of membrane fluidity is affected by its lipid composition, length, amount of unsaturated fatty acids, cholesterol level, and cholesterol/phospholipids ratio (GIRAUD et al., 2000).

Cholesterol plays an important role in phenomena that are related to sperm capacitation
(LANE et al., 1999). The presence of albumin in the female reproductive tract reduces the concentration of cholesterol in the plasma membrane of the spermatozoa as they enter the capacitation phase. This efflux of cholesterol causes the membrane to destabilize and precedes the acrosome reaction (YANAGIMACHI, 1994). The process of cryopreservation increases the number of prematurely capacitated cells, as well as the number of spermatozoa with acrosome reaction before fertilization, which results in decreased fertility (CORMIER et al., 1997).

The addition of specific lipids is beneficial to spermatozoa, conferring greater protection during the cryopreservation process. Improved freezability has been observed with the addition of oleic-linoleic acid dimers (C18:1 n-9 and C18:2 n-9, respectively OLA) and leads to higher spermatozoa motility and viability in post-thawed semen of sheep (PÉREZPÉ et al., 2001; MARTI et al., 2008).

The use of cholesterol increases the cholesterol/ phospholipid ratio and osmotic tolerance, which increases the permeability to cryoprotectants and spermatozoa longevity (MOCÉ et al., 2010). The plant analog of cholesterol ( $\beta$-sitosterol $-\beta$-sit) 
showed similar effects to those of cholesterol on human semen freezing, without the need to use the inclusion complex for its incorporation into the sperm membrane (KHORASANI et al., 2000).

The present study aimed to assess the effect of adding the lipids OLA and $\beta$-sitosterol to the freezing diluent, on motility, vigor, integrity of the plasma and acrosomal membranes, mitocondrial activity, and the level of lipid peroxidation of bovine and equine spermatozoa subject to cryopreservation.

\section{Materials and Methods}

Addition of lipids to the freezing extender of semen of bulls

Adult Nelore bulls maintained in an extensive breeding system in two rural properties were used to conduct Experiments 1 and 2. In both experiments, the bulls were in sexual rest and semen collection was performed via electroejaculation and one ejaculate was obtained per bull. After semen collection and analysis of the physical characteristics, the ejaculate was diluted in freezing media $\left(\right.$ Botubov $^{\circledR}-$ Botupharma Biotecnologia Animal, Botucatu - SP, Brasil), at a concentration of $100 \times 10^{6}$ cells $/ \mathrm{mL}$.

After addition of OLA and $\beta$-sit (Sigma Aldrich, St. Louis, MO, EUA), the aliquots of semen were incubated at $32^{\circ} \mathrm{C}$ for $15 \mathrm{~min}$ and placed in 0.5 $\mathrm{mL}$ straws containing $50 \times 10^{6}$ spermatozoa per straw. The straws were maintained in equilibrium at $5^{\circ} \mathrm{C}$, transported to the laboratory in a polystyrene container, exposed to nitrogen vapor for $20 \mathrm{~min}$ in a conventional polystyrene box, and immersed in liquid nitrogen. Thawing was performed in a water bath at $38^{\circ} \mathrm{C}$ for $30 \mathrm{~s}$.

\section{Experiment 1}

Twelve bulls were used, with a mean age of $30.2 \pm 16.7$ months, mean body condition score of 3.8 (scale of 1 to 5), and mean scrotal perimeter of $35.9 \mathrm{~cm}$. After semen collection and dilution in the cryopreservation media, the lipids were added according to the following treatments: $\mathrm{C}$ - control; $\mathrm{A} 1-37 \mu \mathrm{M}$ of OLA; B1 $-1 \mu \mathrm{g} \mathrm{mL}^{-1}$ of $\beta$-sit, and $\mathrm{AB} 1-37 \mu \mathrm{M}$ of OLA $+1 \mu \mathrm{g} \mathrm{ml}^{-1}$ of $\beta$-sit. In this experiment, the straws remained in equilibrium at $5^{\circ} \mathrm{C}$ for a mean period of $9 \mathrm{~h}$ and $12 \mathrm{~min}$.

The seminal variables were analyzed four times: post-collection (PC), post-equilibium time (PET), post-thaw (PT), and post-capacitation with the addition of heparin at a concentration of $1 \mathrm{mg} \mathrm{mL}^{-1}$ and incubation at $37^{\circ} \mathrm{C}$ for $5 \mathrm{~h}$ (PCap), with the exception of the evaluation of mitochondrial activity and lipid peroxidation, which was performed PT.

\section{Experiment 2}

Twenty bulls were used, with a mean age of 29.9 \pm 3.0 months, mean body condition score of 3.0 (scale 1 to 5), and mean scrotal perimeter of $36.3 \mathrm{~cm}$. The addition of lipids was performed after semen collection and dilution in the cryopreservation media according to the following treatments: $\mathrm{C}-$ control; $\mathrm{A} 2-74 \mu \mathrm{M}$ of AOL; B2 $-2 \mu \mathrm{g} \mathrm{mL}^{-1}$ of $\beta$-sit, and $\mathrm{AB} 2-74 \mu \mathrm{M} \mathrm{AOL}+2 \mu \mathrm{g} \mathrm{mL}^{-1} \beta$-sit. The semen was maintained in equilibrium at $5^{\circ} \mathrm{C}$ for a mean period of $7 \mathrm{~h}$ and $30 \mathrm{~min}$.

The seminal variables were analyzed at three experimental times: PC, PET, and PT, with the exception of the evaluation of mitochondrial activity and lipid peroxidation, which was performed at PT.

\section{Addition of lipids to the freezing diluent of the semen of stallions}

\section{Experiment 3}

Ten adult stallions of known fertility were used. These were of the Quarter Horse $(n=8)$ and Paint Horse $(n=2)$ breeds, with a mean age of $12.3 \pm 4.2$ years, and were subjected to handling procedures adopted by the breeding farms to which they belong. Semen collection was performed using an artificial vagina, Model Botucatu ${ }^{\circledR}$ (Botupharma 
Biotecnologia Animal, Botucatu-SP, Brasil) and one ejaculate was collected per stallion.

After semen collection and evaluation of its physical characteristics, the ejaculate was diluted in skimmed milk-based centrifugation media (Botusêmen $^{\circledR}$ - Botupharma Biotecnologia Animal, Botucatu-SP, Brasil), at a concentration of 25-50 $\times 10^{6}$ spermatozoa per $\mathrm{mL}$, and chilled at $15^{\circ} \mathrm{C}$ in a Equi Sêmen ${ }^{\circledR}$ (MReis) container during its transportation to the laboratory within a maximum interval of $1 \mathrm{~h}$ post collection. Subsequently, the diluted semen was centrifuged at $600 \times g$ for $13 \mathrm{~min}$, the supernatant was discarded and the pellet was resuspended in egg yolk-based diluent (Botucrio $^{\circledR}$ - Botupharma Biotecnologia Animal, Botucatu-SP, Brasil), at a concentration of $200 \times 10^{6}$ spermatozoa per $\mathrm{mL}$.

The lipids were added after resuspension, to the following treatment groups: $\mathrm{C}$ - control group; A1 and $\mathrm{A} 2$ - OLA at concentrations of $37 \mu \mathrm{M}$ and 74 $\mu \mathrm{M}$; $\mathrm{B} 1$ and $\mathrm{B} 2-\beta$-sit at concentrations of $1 \mu \mathrm{g}$ $\mathrm{mL}^{1}$ and $2 \mu \mathrm{gLL}^{-1} ; \mathrm{AB} 1$ and $\mathrm{AB} 2-\mathrm{OLA} 37 \mu \mathrm{M}+$ $\beta$-sit $1 \mu \mathrm{g} \mathrm{mL}^{-1}$ and OLA $74 \mu \mathrm{M}+\beta$-sit $2 \mu \mathrm{g} \mathrm{mL}^{-1}$, respectively.

Subsequently, the semen aliquots were incubated at $32^{\circ} \mathrm{C}$ for $15 \mathrm{~min}$, placed in $0.5 \mathrm{ml}$ straws and chilled at $5^{\circ} \mathrm{C}$ for $20 \mathrm{~min}$. Then, they were exposed to nitrogen vapor for $20 \mathrm{~min}$ and immersed in liquid nitrogen. The samples were thawed at $38^{\circ} \mathrm{C}$ for $30 \mathrm{~s}$.

The seminal variables were analyzed at three time points: PC, post-incubation with lipids (PI), and PT, with the exception of the evaluation of mitochondrial activity and lipid peroxidation, which was performed at PT.

\section{Laboratory tests}

The evaluation of motility/vigor was performed blinded by the same technician. A $10-\mu \mathrm{L}$ aliquot of semen was placed between the slide and the cover slip and maintained on a warmed plate, under brightfield microscopy, using $10 \times$ and $40 \times$ objectives.
The results of spermatozoa motility and vigor were expressed as a percentage and according to a scale from 0 to 5 , respectively.

The concentration of spermatozoa was estimated using a Neubauer chamber at dilutions of 1:200 (experiments 1 and 2) and 1:100 (experiment 3). After semen collection, spermatozoa were counted under bright-field microscopy using a $40 \times$ objective, and the values are expressed as value $\times 10^{6} \mathrm{~mL}^{-1}$.

Sperm viability and acrosome status were assessed using the double staining technique (Trypan blue/Giemsa - TBG) as described by Didion et al. (1989). Two-hundred cells were counted under bright-field microscopy, using a 100× objective, and the spermatozoa were classified as live (L), dead (D), true acrosome reaction (TAR) - live spermatozoa without an acrosome, and false acrosome reaction (FAR) - dead spermatozoa without acrosome.

The mitochondrial activity was evaluated by 3,3'-diaminobenzidin (DAB) staining, as described by Hrudka (1987). Two hundred cells were counted under phase-contrast microscopy, using a $100 \times$ objective. Cells were classified according to the deposition of DAB on the midpiece: DAB I - 100\% of the midpiece was stained; DAB II $->50 \%$ of the midpiece was stained; DAB III $-<50 \%$ of the midpiece was stained; or DAB IV - midpiece not stained.

The evaluation of lipid peroxidation was performed by measuring the concentration of thiobarbituric acid reactive substances (TBARS), according to the protocol described by Nichi et al. (2007). Quantification was performed by spectrophotometry, at a wavelength of $532 \mathrm{~nm}$, and the results were compared against a previously established standard curve of malondialdehyde absorption. The concentration of TBARS was determined using a molar extinction coefficient of malondialdehyde $\left(1.56 \times 10^{5} \mathrm{M} \mathrm{ml}^{-\mathrm{L}}\right)$ and was expressed in nanograms of TBARS per $1 \times 10^{8}$ of spermatozoa. 


\section{Statistical analysis}

The experimental design was performed in subdivided plots considering the addition of OLA and $\beta$-sit at various concentrations as treatments, and the evaluation time points as subplots. Analysis of variance was performed to compare the dependent variables (motility, plasma and acrosomal membrane integrity, mitochondrial activity, and lipid peroxidation), using the GLM procedure within SAS statistical software (2001) and considering the fixed effects of the treatments and the evaluation time points. The means were compared using the Duncan test, at a 5\% level of significance. The variables motility and the levels of TBG (L; D; TAR; FAR) and DAB (DAB I; DAB II; DAB III; DAB IV) staining were transformed according to the method described by Sampaio (1998), and the variable TBARS was $\log _{10}$ transformed.

\section{Results}

\section{Experiment 1}

The motility and vigor values obtained postcollection were $80.0 \% \pm 7.4 \%$ and $3.8 \pm 0.5$, respectively. Motility PC was significantly different from that PF, PT, and PCap $(p<0.05)$ in all treatments, with the exception of treatment
A1, in which motility was not different between the PC and PET. In treatments C and B1, motility was higher PCap than at the PT, which did not occur in treatments $\mathrm{A} 1$ and $\mathrm{AB} 1$. There was no difference between treatments with regard to the post-equilibrium time and post-thaw, within each experimental time (Table 1).

The mean sperm viability and acrosome status after semen collection for the live, dead, TAR and FAR sperm were: $78.0 \% \pm 9.1 \% ; 18.9 \% \pm 8.1 \%$; $0.4 \% \pm 0.5 \%$, and $2.8 \% \pm 2.8 \%$, respectively.

There were no significant differences with regard to sperm viability between the treatments, when compared at the same time point. The variables for live and dead sperm were significantly different between the PET, PT, and PCap $(p<0.05)$ time points within the same treatment. There were no differences between the PT and PCap time points, with the exception of treatment $\mathrm{A} 1$, in which the number of dead cells was lower at the PCap time point than PT. With regard to the variable true acrosome reaction, in treatments $\mathrm{B} 1$ and $\mathrm{AB} 1$ the values were higher PCap than PT, whereas the variable false acrosome reaction the PCap time point was higher than that at the PT time point in all treatments.

Table 1. Mean values ( \pm standard deviation) of motility and vigor of semen from bulls $(n=12)$ with the addition of lipids (post-freeze, post-thaw, and post-capacitation).

\begin{tabular}{|c|c|c|c|c|c|c|}
\hline \multirow{3}{*}{ Treat* } & \multicolumn{6}{|c|}{ Variables/Experimental times } \\
\hline & \multicolumn{3}{|c|}{ Motility (\%) } & \multicolumn{3}{|c|}{ Vigor (0-5) } \\
\hline & $\mathbf{P F}^{* * *}$ & PT & PCap & PF & PT & PCap \\
\hline $\mathrm{C}$ & $67.5 \pm 8.7^{a * * *}$ & $34.2 \pm 15.1^{b}$ & $55.0 \pm 14.1^{\mathrm{c}}$ & $3.9 \pm 0.5^{a}$ & $2.8 \pm 0.5^{b}$ & $3.0 \pm 0.8^{b}$ \\
\hline A1 & $73.6 \pm 81^{a}$ & $35.0 \pm 17.8^{b}$ & $45.0 \pm 14.1^{b}$ & $4.3 \pm 0.8^{a}$ & $2.8 \pm 0.5^{b}$ & $2.8 \pm 0.7^{b}$ \\
\hline B1 & $67.5 \pm 6.2^{\mathrm{a}}$ & $29.2 \pm 10.8^{b}$ & $45.0 \pm 25.1^{c}$ & $3.8 \pm 0.6^{\mathrm{a}}$ & $2.7 \pm 0.5^{b}$ & $2.9 \pm 0.6^{b}$ \\
\hline AB1 & $70.0 \pm 10.4^{a}$ & $36.4 \pm 12.1^{b}$ & $38.1 \pm 21.4^{b}$ & $4.1 \pm 0.7^{\mathrm{a}}$ & $2.7 \pm 0.5^{b}$ & $2.6 \pm 0.7^{b}$ \\
\hline
\end{tabular}

* Treat $=$ Treatment: $\mathrm{C}=$ control; $\mathrm{A} 1=$ oleic-linoleic acid $37 \mu \mathrm{M} ; \mathrm{B} 1=\beta$-sitosterol $1 \mu \mathrm{g} \mathrm{mL} \mathrm{mL}^{-1} ; \mathrm{AB} 1=$ oleic-linoleic acid $37 \mu \mathrm{M}+$ $\beta$-sitosterol $1 \mu \mathrm{g} \mathrm{mL}^{-1}$;

** Time points: $\mathrm{PF}=$ Post-freeze; $\mathrm{PT}=$ Post-thaw; PCap = Post-capacitation;

*** Different lower case letters in the line indicate a significant difference between means for the same variable using the Duncan test $(p<0.05)$, between time points within each treatment.

Source: Elaboration of the authors. 
The results of the evaluation of mitochondrial activity by DAB are shown in Figure 1. There was no statistical difference between the control and the other the treatments in all DAB classes.
The evaluation of lipid peroxidation showed that there were no significant differences between treatments at the PT experimental time (Figure 2).

Figure 1. Effect of oleic-linoleic acid and $\beta$-sitosterol addition to the freezing diluent of bovine semen $(n=10)$ on the post-thaw mitochondrial activity, evaluated via $\mathrm{DAB}$ staining. Treatments: $\mathrm{C}=$ control; $\mathrm{A} 1=$ oleic-linoleic acid 37 $\mu \mathrm{M}$; B1 = $\beta$-sitosterol $1 \mu \mathrm{g} \mathrm{mL}^{-1} ; \mathrm{AB} 1=$ oleic-linoleic acid $37 \mu \mathrm{M}+\beta$-sitosterol $1 \mu \mathrm{g} \mathrm{mL}^{-1}$.

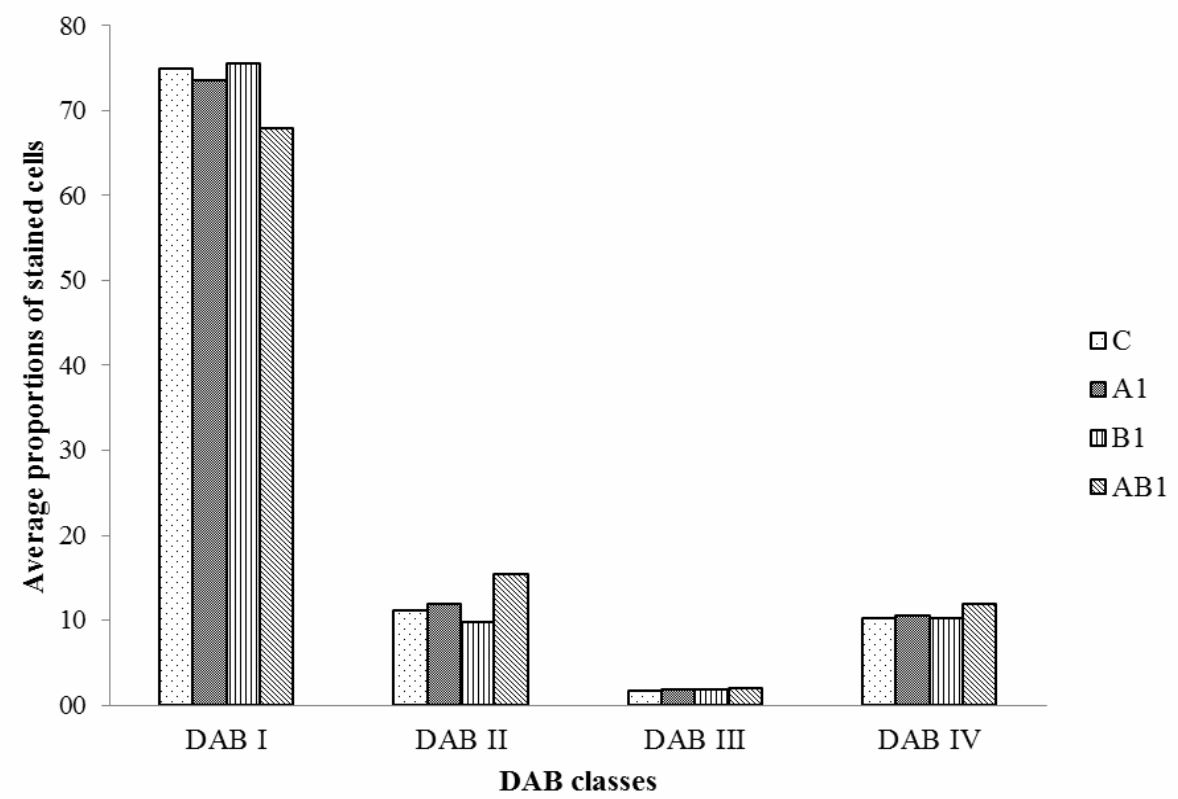

Source: Elaboration of the authors.

Figure 2. Effect of oleic-linoleic acid and $\beta$-sitosterol in the freezing diluent of bovine semen $(\mathrm{n}=10)$ on post-thaw lipid peroxidation, evaluated via the TBARS technique. Treatments: $\mathrm{C}=$ control; $\mathrm{A} 1=$ oleic-linoleic acid $37 \mu \mathrm{M} ; \mathrm{B} 1$ $=\beta$-sitosterol $1 \mu \mathrm{g} \mathrm{mL}^{-1} ; \mathrm{AB} 1=$ oleic-linoleic acid $37 \mu \mathrm{M}+\beta$-sitosterol $1 \mu \mathrm{g} \mathrm{mL}^{-1}$.

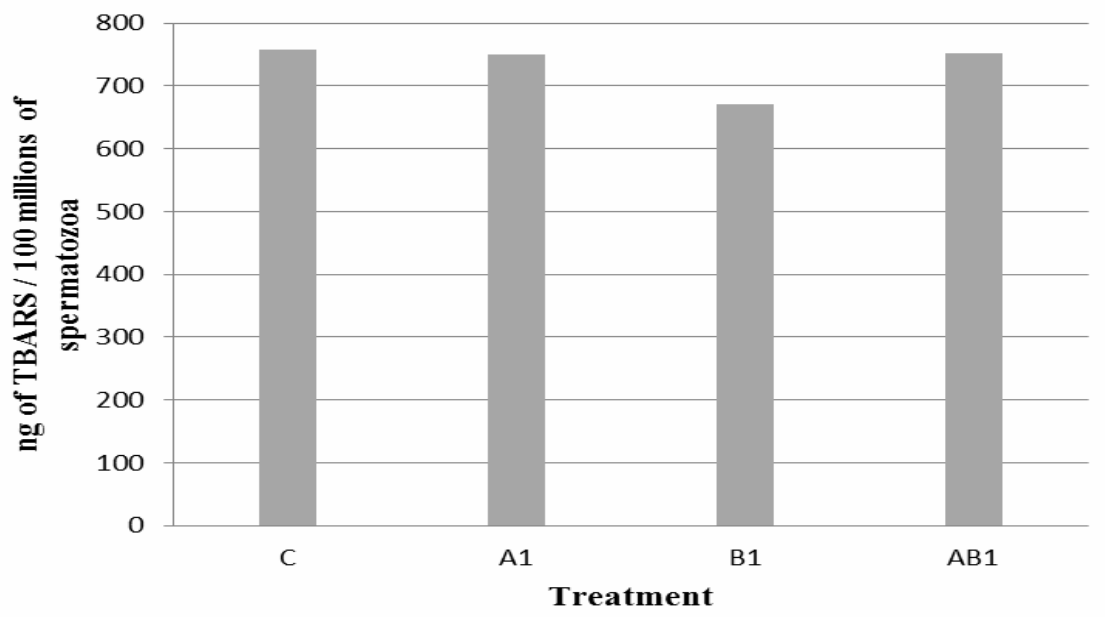

Source: Elaboration of the authors. 


\section{Experiment 2}

The mean post-collection values obtained for motility and vigor were $78.0 \pm 4.1$ and $3.7 \pm 0.5$, respectively. Motility at the PC time point differed $(p<0.05)$ from that at the PET and PT experimental times. Values of vigor observed in treatment $\mathrm{AB} 2$ were significantly lower at PET than at the PT time point $(p<0.05)$; however, no differences were observed in the remaining treatments.

The variables were similar between treatments at the PET time point; in contrast, at PT, treatments B2 and $\mathrm{AB} 2$ exhibited lower motility and vigor than did the control group (Table 2).

Table 2. Mean values ( \pm standard deviation) of motility and vigor of the semen from bulls $(\mathrm{n}=20)$ following the addition of lipids (post-freeze and post-thaw).

\begin{tabular}{|c|c|c|c|c|}
\hline \multirow{3}{*}{ Treatment } & \multicolumn{4}{|c|}{ Variables/Experimental times } \\
\hline & \multicolumn{2}{|c|}{ Motility (\%) } & \multicolumn{2}{|c|}{ Vigor $(0-5)$} \\
\hline & $\mathbf{P F}^{* *}$ & PT & PF & PT \\
\hline $\mathrm{C}$ & $73.0 \pm 8.6^{\mathrm{a}}$ & $51.0 \pm 13.7^{\mathrm{bA}}$ & $3.6 \pm 0.5^{\mathrm{a}}$ & $2.9 \pm 0.4^{\mathrm{bA}}$ \\
\hline A2 & $72.0 \pm 7.0^{\mathrm{a}}$ & $47.5 \pm 15.2^{\mathrm{bAB}}$ & $3.4 \pm 0.6^{\mathrm{a}}$ & $2.7 \pm 0.7^{\mathrm{bAB}}$ \\
\hline B2 & $69.5 \pm 11.0^{\mathrm{a}}$ & $35.8 \pm 15.8^{\mathrm{bC}}$ & $3.5 \pm 0.6^{\mathrm{a}}$ & $2.3 \pm 0.6^{\mathrm{bC}}$ \\
\hline $\mathbf{A B 2}$ & $71.5 \pm 10.9^{\mathrm{a}}$ & $38.5 \pm 16.6^{\mathrm{bBC}}$ & $3.3 \pm 0.6^{\mathrm{a}}$ & $2.5 \pm 0.5^{\mathrm{b} \mathrm{BC}}$ \\
\hline
\end{tabular}

* Treatments: $\mathrm{C}=$ control; $\mathrm{A} 2=$ oleic-linoleic acid $74 \mu \mathrm{M} ; \mathrm{B} 2=\beta$-sitosterol $2 \mu \mathrm{g} \mathrm{mL} \mathrm{mL}^{-1}$; $\mathrm{AB} 2=$ oleic-linoleic acid $74 \mu \mathrm{M}+$ $\beta$-sitosterol $2 \mu \mathrm{g} \mathrm{mL}-1$

** Time points: $\mathrm{PF}=$ Post-freeze; $\mathrm{PT}=$ Post-thaw

*** Different lower case letters in the line indicate a significant difference between means for the same variable using the Duncan test $(p<0.05)$, between time points within each treatment. Different upper case letters in the column indicate a significant difference between the treatments for the same variable using the Duncan test $(p<0.05)$.

Source: Elaboration of the authors.

The mean results obtained in the post-collection analysis of sperm viability and acrosome status were: $89.0 \pm 6.5,8.9 \pm 5.9,0.8 \pm 1.1$, and $1.2 \pm 0.8$ for the live, dead, TAR, and FAR sperm, respectively.

There were no significant differences with regard to sperm viability between treatments when compared at the same experimental time. There was a difference between the PET and PT $(p<0.05)$ in the live and dead classes when compared within the same treatment; however, the variables TAR and
FAR did not differ significantly between treatments or between time points.

The analysis of mitochondrial activity did not show statistical differences between treatments within each DAB class at the post-thaw time point (Figure 3).

Moreover, the evaluation of lipid peroxidation at PT was not significantly different between treatments (Figure 4). 
Figure 3. Effect of oleic-linoleic acid and $\beta$-sitosterol in the freezing diluent of bovine semen $(\mathrm{n}=20)$ on post-thaw mitochondrial activity, evaluated via staining with 3,3'- diaminobenzidine (DAB). Treatments: $\mathrm{C}=\mathrm{Control}$; $\mathrm{A} 2=$ oleic-linoleic acid $74 \mu \mathrm{M}$; B2 $=\beta$-sitosterol $2 \mu \mathrm{g} \mathrm{mL}{ }^{1}$; AB2 $=$ oleic-linoleic acid $74 \mu \mathrm{M}+\beta$-sitosterol $2 \mu \mathrm{g} \mathrm{mL}^{-1}$.

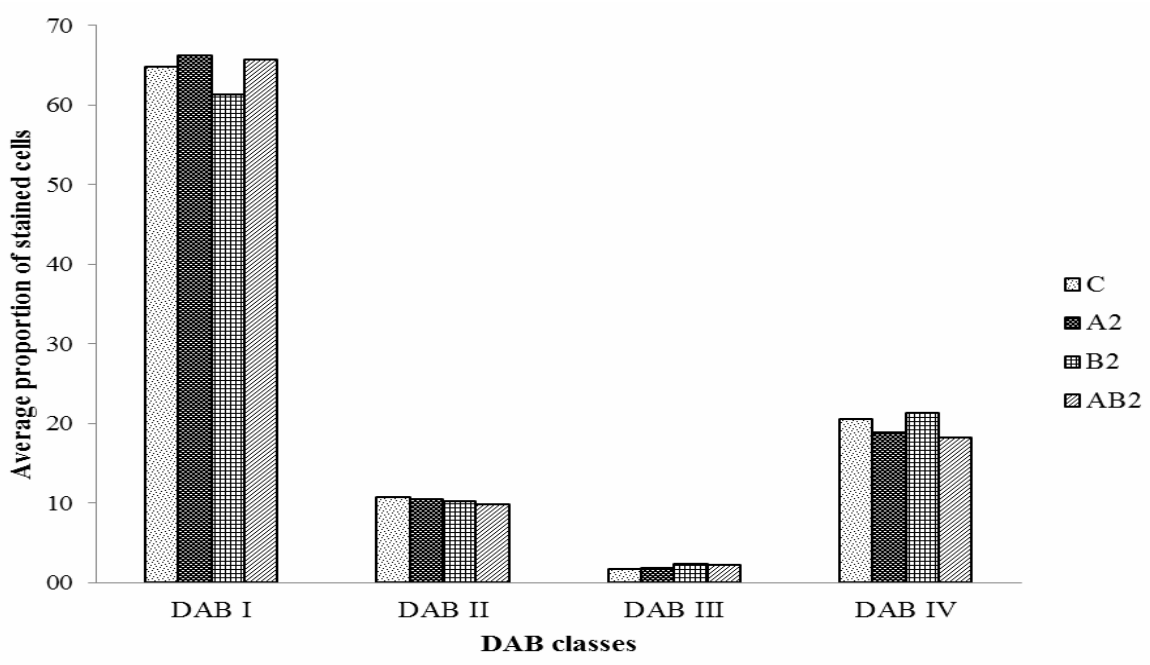

Source: Elaboration of the authors.

Figure 4. Effect of oleic-linoleic acid and $\beta$-sitosterol in the freezing diluent of bovine semen $(n=20)$ on post-thaw lipid peroxidation, evaluated via the TBARS technique. Treatments: $\mathrm{C}=$ control; $\mathrm{A} 2=$ oleic-linoleic acid $74 \mu \mathrm{M}$; B2 $=\beta$-sitosterol $2 \mu \mathrm{g} \mathrm{mL}^{-1} ; \mathrm{AB} 2=$ oleic-linoleic acid $74 \mu \mathrm{M}+\beta$-sitosterol $2 \mu \mathrm{g} \mathrm{mL}{ }^{-1}$.

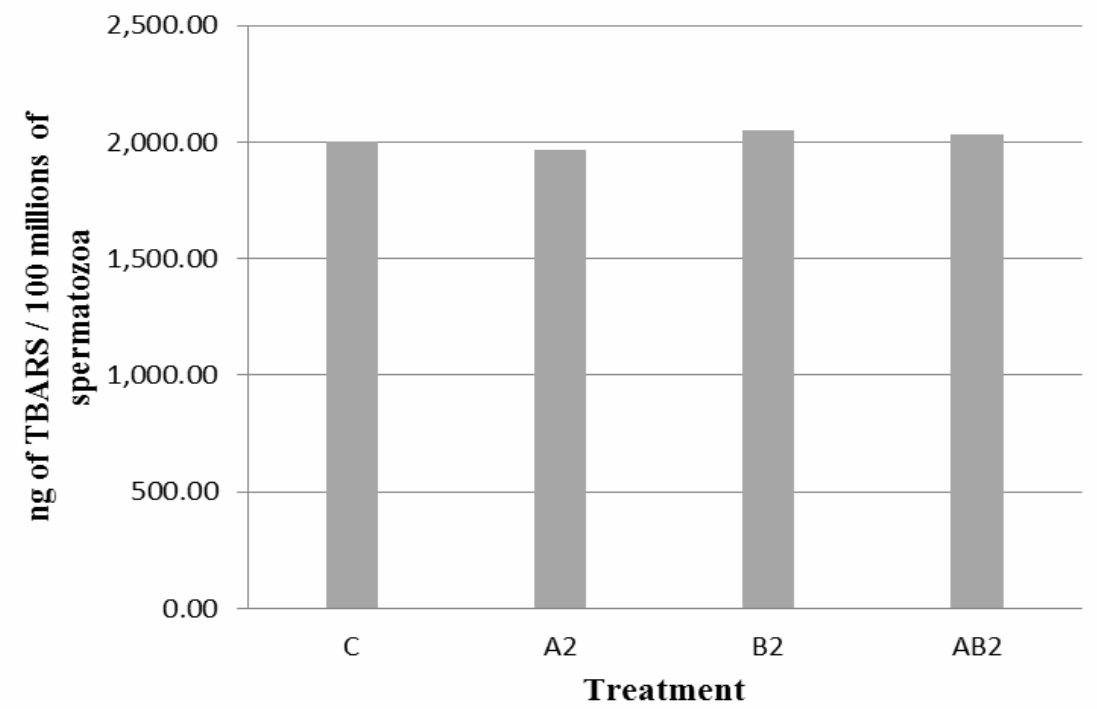

Source: Elaboration of the authors. 


\section{Experiment 3}

The post-collection values of motility and vigor for the equine semen were $79.0 \pm 3.2 \%$ and $4.0 \pm 0.0$, respectively. The post-collection results were significantly different $(p<0.0001)$ from the post-thaw results in all treatments. There was a significant difference between the post-incubation and the post-thaw time points; however, at the same experimental time these variables were not different between treatments (Table 3 ).

Table 3. Mean values ( \pm standard deviation) of motility and vigor of equine semen $(n=10)$, after incubation with lipids at $32^{\circ} \mathrm{C} / 15 \mathrm{~min}$ and post-thaw.

\begin{tabular}{|c|c|c|c|c|}
\hline \multirow{3}{*}{ Treat* } & \multicolumn{4}{|c|}{ Variables/Experimental times** } \\
\hline & \multicolumn{2}{|c|}{ Motility (\%) } & \multicolumn{2}{|c|}{ Vigor $(0-5)$} \\
\hline & PI & PT & PI & PT \\
\hline $\mathbf{C}$ & $78.0 \pm 4.2^{\mathrm{a}^{* * *}}$ & $54.0 \pm 17.1^{\mathrm{b}}$ & $4.1 \pm 0.6^{\mathrm{a}}$ & $2.9 \pm 0.7^{b}$ \\
\hline A1 & $83.0 \pm 6.7^{\mathrm{a}}$ & $60.0 \pm 15.6^{b}$ & $4.0 \pm 0.5^{\mathrm{a}}$ & $3.0 \pm 0.7^{b}$ \\
\hline B1 & $83.0 \pm 6.7^{\mathrm{a}}$ & $61.0 \pm 14.5^{b}$ & $4.3 \pm 0.7^{\mathrm{a}}$ & $2.9 \pm 0.9^{b}$ \\
\hline AB1 & $87.0 \pm 6.7^{\mathrm{a}}$ & $64.0 \pm 11.7^{\mathrm{b}}$ & $4.4 \pm 0.5^{\mathrm{a}}$ & $3.1 \pm 0.6^{b}$ \\
\hline $\mathbf{A 2}$ & $82.0 \pm 6.3^{\mathrm{a}}$ & $64.0 \pm 13.5^{b}$ & $4.1 \pm 0.3^{\mathrm{a}}$ & $3.1 \pm 0.7^{b}$ \\
\hline B2 & $79.0 \pm 3.2^{\mathrm{a}}$ & $59.0 \pm 15.2^{b}$ & $4.3 \pm 0.8^{a}$ & $3.2 \pm 0.6^{\mathrm{b}}$ \\
\hline AB2 & $83.0 \pm 4.8^{\mathrm{a}}$ & $55.0 \pm 15.1^{\mathrm{b}}$ & $4.3 \pm 0.5^{\mathrm{a}}$ & $3.0 \pm 0.8^{b}$ \\
\hline
\end{tabular}

* Treatments: $\mathrm{C}=$ control; $\mathrm{A} 1=$ oleic-linoleic acid $37 \mu \mathrm{M} ; \mathrm{A} 2=$ oleic-linoleic acid $74 \mu \mathrm{M} ; \mathrm{B} 1=\beta$-sitosterol $1 \mu \mathrm{g} \mathrm{mL}{ }^{-1}$; $\mathrm{B} 2=$ $\beta$-sitosterol $2 \mu \mathrm{g} \mathrm{mL}$; $\mathrm{AB} 1=$ oleic-linoleic acid $37 \mu \mathrm{M}+\beta$-sitosterol $1 \mu \mathrm{g} \mathrm{mL}{ }^{-1} ; \mathrm{AB} 2=$ oleic-linoleic acid $74 \mu \mathrm{M}+\beta$-sitosterol 2 $\mu \mathrm{g} \mathrm{mL} L^{-1}$

** PI $=$ Post-incubation; PT $=$ Post-thaw

*** Different lower case letters in the line indicate significant difference between means for the same variable using the Duncan test $(p<0.05)$

$(p>0.05)$ between treatments within each moment.

Source: Elaboration of the authors.

The mean post-collection percentages for the live, dead, TAR, and FAR sperm were: $71.3 \% \pm$ $10.0 \%, 22.6 \% \pm 9.6 \%, 1.8 \% \pm 1.4 \%$, and $4.4 \% \pm$ $2.1 \%$, respectively. The results from the PC and PI time points were statistically similar; however, there was a significant difference between the postcollection values and those observed post-thaw $(p$ $<0.0001)$.

The analysis of sperm viability and acrosome status post-incubation and post-thaw were not significantly different between treatments. The results from the PI time point differed significantly from those of the PT time point for live $(p<0.0001)$, dead $(p<0.0001)$, and FAR $(p<0.0005)$; however, there was no significant difference between time points with regard to TAR.

Figures 5 and 6 show the results obtained in the evaluation of mitochondrial activity and lipid peroxidation at the PT time point, respectively. In both tests, there was no significant difference between treatments. 
Figure 5. Effect of oleic-linoleic acid and $\beta$-sitosterol addition to the freezing diluent of equine semen $(\mathrm{n}=10)$ on post-thaw mitochondrial activity, evaluated via $\mathrm{DAB}$ staining. Treatments: $\mathrm{C}=$ control; $\mathrm{A} 1=$ oleic-linoleic acid 37 $\mu \mathrm{M}$; B1 $=\beta$-sitosterol $1 \mu \mathrm{g} \mathrm{ml}^{-1} ; \mathrm{AB} 1=$ oleic-linoleic acid $37 \mu \mathrm{M}+\beta$-sitosterol $1 \mu \mathrm{g} \mathrm{mL}^{-1} ; \mathrm{A} 2=$ oleic-linoleic acid 74 $\mu \mathrm{M} ; \mathrm{B} 2=\beta$-sitosterol $2 \mu \mathrm{g} \mathrm{mL}^{-1} ; \mathrm{AB} 2=$ oleic-linoleic acid $74 \mu \mathrm{M}+\beta$-sitosterol $2 \mu \mathrm{g} \mathrm{mL}^{-1}$.

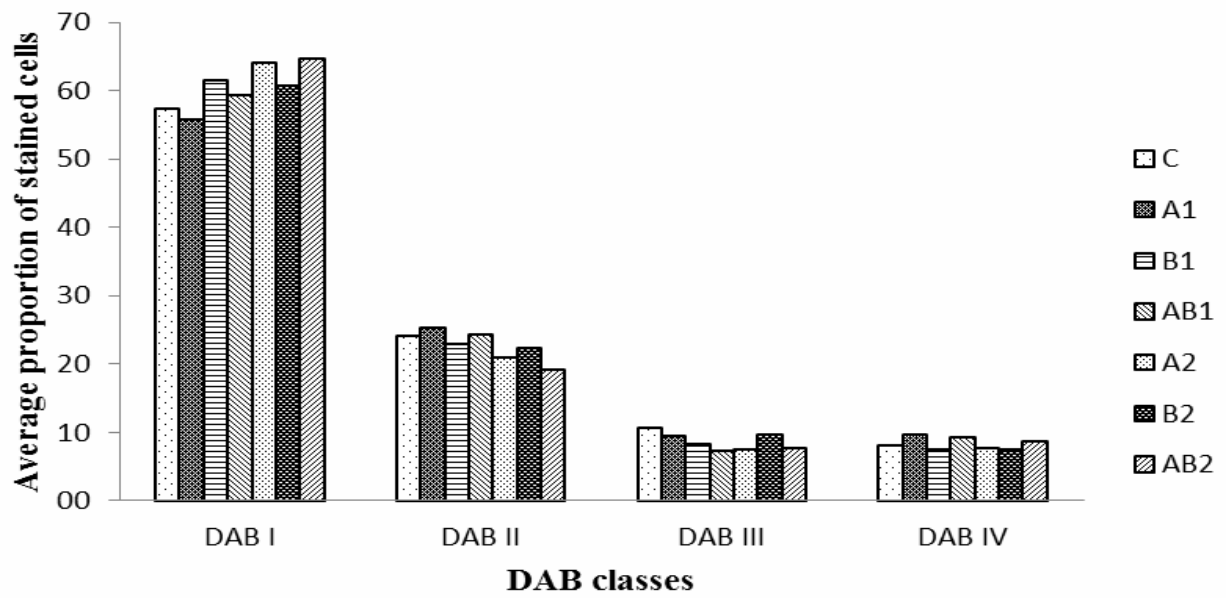

Source: Elaboration of the authors.

Figure 6. Effect of oleic-linoleic acid and $\beta$-sitosterol addition to the freezing diluent of equine semen $(\mathrm{n}=10)$ on post-thaw lipid peroxidation, evaluated via the TBARS technique. Treatments: $\mathrm{C}=$ control; $\mathrm{A} 1=$ oleic-linoleic acid $37 \mu \mathrm{M}$; B1 $=\beta$-sitosterol $1 \mu \mathrm{g} \mathrm{mL}-1$; $\mathrm{AB} 1=$ oleic-linoleic acid $37 \mu \mathrm{M}+\beta$-sitosterol $1 \mu \mathrm{g} \mathrm{mL} \mathrm{m}^{-1} ; \mathrm{A} 2=$ oleic-linoleic acid $74 \mu \mathrm{M}$; B2 $=\beta$-sitosterol $2 \mu \mathrm{g} \mathrm{mL} \mathrm{m}^{-1}$; $\mathrm{AB} 2=$ oleic-linoleic acid $74 \mu \mathrm{M}+\beta$-sitosterol $2 \mu \mathrm{g} \mathrm{mL}^{-1}$.

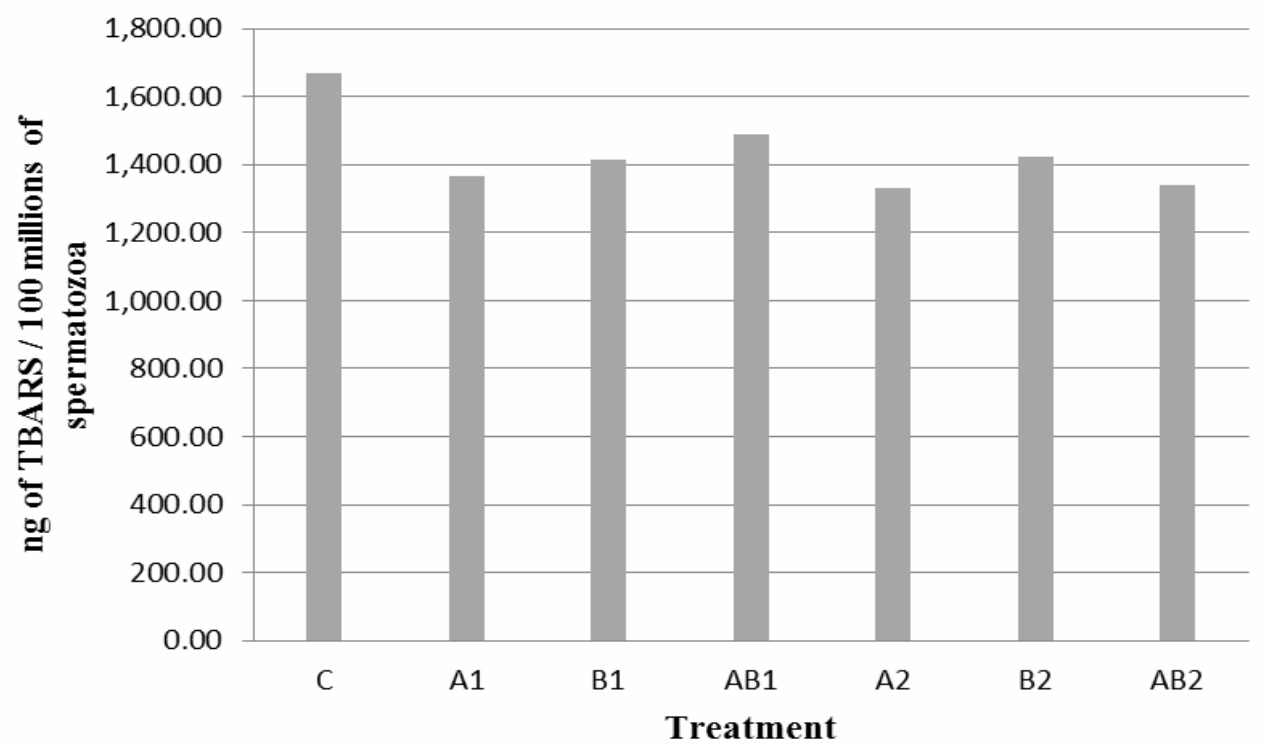

Source: Elaboration of the authors. 


\section{Discussion}

The results of this study are different from those reported by Takahashi et al. (2012); however, these authors assessed the addition of linoleic acid to the freezing diluent using bulls that had semen with low freezability. The authors did not find differences between the control group and the group subjected to short-term incubation $\left(4 \mathrm{~h}\right.$ at $\left.4^{\circ} \mathrm{C}\right)$ with linoleic acid (18:2 $\mathrm{n}=6)$ after thawing; however, they observed higher values for progressive motility after incubation for $30 \mathrm{~h}$ at $4^{\circ} \mathrm{C}$. They suggested that this improvement was due to the incorporation of linoleic acid into the lipid bilayer, thus providing higher fluidity to the membrane and improving the cryoresistance of semen. The mean freezing times used in Experiments 1 and 2 were $9.2 \pm 1.7 \mathrm{~h}$ and $7.5 \pm 1.2 \mathrm{~h}$, respectively. The fact that in Experiment 3 the freezing time was only 20 min (even with the additional $15 \mathrm{~min}$ incubation at $32^{\circ} \mathrm{C}$ ), may have contributed to the limited incorporation of fatty acids into the lipid bilayer.

When comparing egg yolk-based and milk-egg yolk-based diluents, Salazar et al. (2011) concluded that a slow cooling rate $\left(-0.3^{\circ} \mathrm{C} \mathrm{min}^{-1}\right.$, between $22^{\circ} \mathrm{C}$ and $10^{\circ} \mathrm{C}$ and $-0.2^{\circ} \mathrm{C} \mathrm{min}^{-1}$, between $10^{\circ} \mathrm{C}$ and $4^{\circ} \mathrm{C}$ ) for approximately $70 \mathrm{~min}$, combined with the egg yolk-based diluent yielded better equine semen thawing results, although the slow cooling also improved the seminal variables when milk-egg yolk-based diluent was used. The authors suggested the lipids in the egg yolk interacted with the bilayer of the sperm membrane, and that this association could be improved with the use of emulsifiers. Therefore, by increasing the pre-freezing cooling time it is possible to obtain a stronger interaction between the added lipids and the plasma membrane.

The freezing protocols are different for semen obtained from equine and bovine species, mainly with regard to the adopted equilibrium period. A period of $4 \mathrm{~h}$ at $5^{\circ} \mathrm{C}$ is recommended for bovine sperm (FOOTE; KAPROTH, 2002; THUN et al., 2002), whereas this may vary for equines. The comparison between a cooling period lasting $20 \mathrm{~min}$ and $24 \mathrm{~h}$ did not affect the sperm motility, viability, and pregnancy rates (MELO et al., 2005). Another relevant aspect is the cholesterol/phospholipids ratio in the plasma membrane of spermatozoa, which in equines is 0.36 , a value that is lower than that found in bovines, which is 0.45 (AMANN; GRAHAM, 2011). In these species, spermatozoa are more susceptible to thermal stress when subjected to low temperatures than in species that exhibit a higher cholesterol:phospholipids ratio in the membrane, such as humans and rabbits (MOCÉ et al., 2010).

Researchers have tested the effects of cholesterol addition to bull and stallion semen using an inclusion complex with cyclodextrin; they observed a modification in the cholesterol:phospholipids ratio in spermatozoa that may have contributed to the stabilization of the membrane (PURDY; GRAHAM, 2004; MOORE et al., 2005). The increase in stability provides greater protection against the deleterious effects of the freeze-thaw process (MOCÉ et al., 2010). Despite the improved freezability of bull semen (MOCÉ; GRAHAM, 2006), the fertility rates were not different between the group in which cholesterol was added to the semen and the control group (PURDY; GRAHAM, 2004). Spizziri et al. (2010), observed the improvement of progressive motility of equine semen when cholesterol combined with cyclodextrin was added to the centrifugation extender; however, Oliveira et al. (2010) did not observe an improvement in motility after thawing when cholesterol was added to the semen of stallions. In the present study, the addition of a plant substance equivalent of cholesterol, alone or combined with OLA, did not result in significantly different values of motility and vigor in the treatments of Experiments 1 and 3. However, in Experiment 2 there was a reduction in motility and vigor in the groups in which $2 \mu \mathrm{g} \mathrm{mL}^{-1}$ of $\beta$-sitosterol (B2) and $74 \mu \mathrm{M}$ of oleic-linoleic acid combined with $2 \mu \mathrm{g} \mathrm{ml}^{-1}$ of $\beta$-sitosterol (AB2) were added.

These results are also different from those reported by Pérez-Pé et al. (2001), who tested 
various concentrations of OLA in ovine semen in order to protect sperm cells from the effects of thermal stress. The authors concluded that OLA at a concentration of $37 \mu \mathrm{M}$ resulted in a higher number of viable cells after incubation, and that lower concentrations provided cells with less protection. In the same experiment, the results obtained with OLA at a concentration of $74 \mu \mathrm{M}$ were poorer than those obtained at $37 \mu \mathrm{M}$; however, the protective effects were better compared to OLA concentrations lower than $37 \mu \mathrm{M}$. Experiments 1, 2, and 3 tested the addition of OLA at $37 \mu \mathrm{M}, 74 \mu \mathrm{M}$, and both (37 $\mu \mathrm{M}$ and $74 \mu \mathrm{M})$, respectively. These concentrations provided protection against the negative effects of thermal stress in ovine semen; however, no beneficial effect was observed both in the bovine or equine semen.

In addition to the observed beneficial effects on motility/vigor and sperm viability by the addition of cholesterol to the semen of bovines, ovines, and equines, the use of this lipid (OLA) increases the osmotic resistance of spermatozoa and the permeability of the membrane to water and cryoprotectants, which in turn contribute to the stabilization of the membrane and increase cryoresistance (GLAZAR et al., 2009). Awad (2011) concluded that the addition of cholesterol to the freezing extender, with a concentration of glycerol lower than the recommended $(3 \%)$, resulted in higher values of sperm viability and motility in the semen of ovines when compared with the control group in which the concentration of glycerol was the recommended for the species $(6 \%)$, thus reducing the toxic effects of glycerol. In the present study, commercial freezing extenders $\left(\right.$ Botubov $^{\circledR}$ and Botucrio ${ }^{\circledR}$ ) were used; the formulation of these products is patented. The quantity and type of cryoprotectant used in the media to freeze bovine semen is not known; however, Botucrio ${ }^{\circledR}$ uses a mixture of $1 \%(\mathrm{v} / \mathrm{v})$ glycerol and $4 \%(\mathrm{v} / \mathrm{v})$ methylformamide (SIEME, 2011), which probably results in low toxicity to the equine spermatozoa.
The addition of cholesterol may cause a reduction in the rate of acrosome reaction and the time in the female reproductive tract required for this phenomenon to occur probably increases, which in turn reduces fertility rates (MOCÉ et al., 2010). Zahn et al. (2002) reported that the in vivo fertility values were lower when frozen stallion semen with added cholesterol-methyl- $\beta$-cyclodextrin complex was used than when untreated semen was used. In the present study, at the tested doses, the addition of the plant substance equivalent of cholesterol did not change the number of spermatozoa exhibiting true or false acrosome reaction after bovine and equine semen freezing.

In humans, the use of $\beta$-sitosterol showed similar results to those obtained with the addition of the cholesterol-methyl- $\beta$-cyclodextrin complex, and the rates of spontaneous and dose-dependent progesterone-induced acrosome reaction decreased (KHORASANI et al., 2000). The authors demonstrated that the inhibitory action of these lipids is probably regulated by signaling pathways that alter the rigidity of the plasma membrane in a similar manner and prevent the interaction between progesterone and its receptors in a non-competitive manner. In Experiment 1, the addition of $1 \mu \mathrm{g} \mathrm{mL} \mathrm{m}^{-1}$ of $\beta$-sitosterol did not prevent the acrosome reaction in the spermatozoa subjected to capacitation with heparin. Gallová et al. (2011) compared the interaction of cholesterol and $\beta$-sitosterol with phosphatidylcholine and concluded that the behavior of both lipids was similar in terms of incorporation into the phospholipid bilayer, and that they were located in the hydrophobic region of the membrane.

Studies investigating the addition of plant equivalents of cholesterol are still scarce, and the effects of adding these lipids to semen and of their incorporation into the sperm membrane, remain unknown and may constitute alternatives for the modification of the lipid pattern of these cells.

Mitochondrial activity was assessed by DAB staining, which reacts with cytochrome $\mathrm{C}$ in the 
respiratory chain. Cytochrome $\mathrm{C}$ is oxidized and reduced during aerobic metabolism and diaminobenzidine donates an electron to cytochrome $\mathrm{C}$, which becomes reduced and simultaneously undergoes polymerization due to oxidation, resulting in a stained and unsoluble product (HRUDKA, 1987). This staining is used to evaluate the ability of the mitochondria to produce ATP, which sustains the activity of spermatozoa and is thus positively correlated both with cellular motility and viability (GARNER et al., 1997). In addition, mitochondrial activity is related to $\mathrm{Ca}^{2+}$ homeostasis and to the production of reactive oxygen species (ROS) that, at controlled levels, are part of the physiological events associated with fertilization (AMARAL et al., 2013). In the present study, the addition of lipids had no effect on mitochondrial activity in bovines or in equines.

Oxidative stress occurs when the production of ROS exceeds the antioxidation capacity of semen and becomes harmful to the plasma membrane. This results in the production of metabolites such as malondialdehyde (AITKEN et al., 2012) that can be measured via spectrophotometry using the TBARS assay. Although the incorporation of polyunsaturated fatty acids into the membrane increases its flexibility, it can make it more susceptible to lipid peroxidation, which in turn reduces sperm viability (TOWHIDI; PARKS, 2012).

The process of cryopreservation increases lipid peroxidation and can lead to an irreversible rearrangement of membrane lipids; these factors can compromise the fertilizing capacity of spermatozoa (RICKER et al., 2006). In this study, the addition of OLA, $\beta$-sitosterol, or both did not significantly alter the production of malondialdehyde and, therefore, at the tested concentrations, the incorporation of these lipids did not lead to an increase in lipid peroxidation.

High concentrations of saturated fatty acids in the membrane are related to low seminal quality, whereas higher concentrations of polyunsaturated fatty acids positively correlate with membrane integrity in spermatozoa. Understanding the lipid profile of spermatozoa allows for the concentrations of membrane fatty acids to be altered to permit their addition at suitable concentrations in vitro or through dietary supplementation. The in-turn would improve the reproductive performance of stallions that exhibit low freezability because of changes in the spermatozoa membrane lipid profile (GARCIA et al., 2011). The semen from the animals used in this experiment exhibited good freezability, which may have been a factor responsible for the absence of significant differences between treatments. In addition, Argov-Argaman et al. (2013) analyzed the lipid composition of young and adult bull semen and observed low concentrations of fatty acids in the spermatozoa from the adult bovines, which may reduce membrane fluidity and in turn affect their cryoresistance. Young bulls were used in the present study and, therefore, age may have been responsible for the absence of a response to the in vitro addition of the tested lipids.

\section{Conclusion}

The tested concentrations of OLA and $\beta$-sitosterol did not increase the resistance of bovine and equine spermatozoa to the cryopreservation process and were thus ineffective in preserving the structural integrity of the plasma and acrosome membranes. Moreover, they did not alter the levels of mitochondrial activity and lipid peroxidation. Further research is necessary to evaluate the effects of different periods of incubation of the ejaculate with these lipids on the semen of breeding animals of various ages that exhibit low freezability.

\section{Acknowledgements}

The authors thank Botupharma Biotecnologia Animal for providing the extenders and CNPq for granting the postgraduate scholarships. 


\section{References}

AITKEN, J. R.; JONES, K. T.; ROBERTSON, S. A. Reactive oxygen species and sperm function - in sickness and in health. Journal of Andrology, Philadelphia, v. 33, n. 6, 1096-1106, 2012.

AMANN, R. P.; GRAHAM, J. K. Spermatozoal function. In: MCKINNON, A. O.; SQUIRES, E. L.; VAALA, W. E.; VARNER, D. D. (Ed.). Equine reproduction. 2. ed. Oxford: Wiley-Blackwell Publishing Ltd, 2011. cap. 102, p. 1053-1084.

AMARAL, A.; LOURENÇO, B.; MARQUES, M.; RAMALHO-SANTOS, J. Mitochondria functionality and sperm quality. Reproduction, Cambridge, v. 146, n. 5, p. 163-174, 2013.

ARGOV-ARGAMAN, N.; MAHGREFTHE, K.; ZERON, Y.; ROTH, Z. Variation in lipid profiles within semen compartments - the bovine model of aging. Theriogenology, Philadelphia, v. 80, n. 7, p. 712-721, 2013.

AWAD, M. M. Effects of sub-optimal glycerol concentration and cholesterol-loaded cyclodextrin in a Tris-based diluent on cryopreserved ram sperm longevity and acrosomal integrity. Small Ruminant Research, Amsterdam, v. 100, n. 2-3, p. 164-168, 2011.

CORMIER, N.; SIRARD, M. A.; BAILEY, J. L. Premature capacitation of bovine spermatozoa is initiated by cryopreservation. Journal of Andrology, Philadelphia, v. 18 , n. 4 , p. $461-468,1997$.

DIDION, B. A.; DOBRINSKI, J. R.; GILES, J. R.; GRAVES, C. N. Staining procedure to detect viability and the true acrosome reaction in spermatozoa of various species. Gamete Research, New York, v. 22, n. 1, p. 5157, 1989.

FOOTE, R. H.; KAPROTH, M. T. Large batch freezing of bull semen: effect of time of freezing and fructose on fertility. Journal of Dairy Science, Madison, v. 85, n. 2, p. 453-456, 2002.

GALLOVÁ, J.; UHRÍKOVÁ, D.; KUČERKA, N.; SVORKOVÁ, M.; FUNARI, S. S.; MURUGOVA, T. N.; ALMÁSY, L.; MAZÚR, M.; BALGAVÝ, P. Influence of cholesterol and $\beta$-sitosterol on the structure of EYPC bilayers. Journal of Membranes Biology, New York, v. 243, n. 1-3, p. 1-13, 2011.

GARCÍA, B. M.; FERNÁNDEZ, L. G.; FERRUSOLA, C. O.; SALAZAR-SANDOVAL, C.; RODRIGUEZ, A. M.; MARTINEZ, H. R.; TAPIA, J. A.; MORCUENDE, D.; PEÑA, F. J. Membrane lipids of the stallion spermatozoon in relation to sperm quality and susceptibility to lipid peroxidation. Reproduction in Domestic Animals, Berlin, v. 46, n. 1, p. 141-148, 2011.
GARNER, D. L.; THOMAS, C. A.; JOERG, H. W.; DEJARNETTE, J. M.; MARSHALL, C. E. Fluorometric assessments of mitochondrial function and viability in cryopreserved bovine spermatozoa. Biology of Reproduction, New York, v. 57, n. 6, p. 1401-1406, 1997.

GIRAUD, M. N.; MOTTA, C.; BOUCHER, D.; GRIZARD, G. Membrane fluidity predicts the outcome of cryopreservation of human spermatozoa. Human Reproduction, Oxford, v. 15, n. 10, p. 2160-2164, 2000.

GLAZAR, A. I.; MULLEN, S. F.; LIU, J.; BENSON, J. D.; CRITSER, J. K.; SQUIRES, E. L.; GRAHAM, J. $\mathrm{K}$. Osmotic tolerance limits and membrane permeability characteristics of stallion spermatozoa treated with cholesterol. Cryobiology, Rockville, v. 59, n. 2, p. 201206, 2009.

HRUDKA, F. Cytochemical and ultracytochemical demonstration of cytochrome c oxidase in spermatozoa and dynamics of its changes accompanying ageing or induced by stress. International Journal of Andrology, Copenhagen, v. 11, n. 5, p. 809-828, 1987.

KHORASANI, A. M.; CHEUNG, A. P.; LEE, C. Y. G. Cholesterol inhibitory effects on human sperm-induced acrosome reaction. Journal of Andrology, Philadelphia, v. 21, n. 4 , p. $586-594,2000$.

LANE, M. E.; THÉRIEN, I.; MOREAU, R.; MANJUNATH, P. Heparin and high-density lipoprotein mediate bovine sperm capacitation by different mechanisms. Biology of Reproduction, New York, v. 60, n. 1, p. 169-175, 1999.

MARTI, E.; MARTI, J. I.; MUIÑO-BLANCO, T.; CEBRIÁN-PÉREZ, J. A. Effect of the cryopreservation process on the activity and immunolocalization of antioxidant enzymes in ram spermatozoa. Journal of Andrology, Philadelphia, v. 29, n. 4, p. 459-467, 2008.

MELO, C. M.; ZAHN, F. S.; MARTIN, I.; ALBERTI, K.; ORLANDI, C.; SIQUEIRA FILHO, E. R.; DELL'AQUA JR, J. A.; ALVARENGA, M. A.; PAPA, F. O. Effects of cooling stallion semen for $24 \mathrm{~h}$ before freezing on fertility rates. Animal Reproduction Science, Amsterdam, v. 89, n. 1-4, p. 250-252, 2005.

MOCÉ, E.; GRAHAM, J. K. Cholesterol-loaded cyclodextrins added to fresh bull ejaculates improves sperm cryosurvival. Journal of Animal Science, Champaign, v. 84, n. 4, p. 826-833, 2006.

MOCÉ, E.; BLANCH, E.; TOMÁS, C.; GRAHAM, J. K. Use of cholesterol in sperm cryopreservation: present moment and perspectives to future. Reproduction in Domestic Animals, Berlin, v. 45, p. 57-66, 2010. Supplement 2. 
MOORE, A. I.; SQUIRES, E. L.; GRAHAM, J. K. Adding cholesterol to the stallion sperm plasma membrane improves cryosurvival. Cryobiology, Rockville, v. 51, n. 3, p. 241-249, 2005.

NICHI, M.; GOOVAERTS, I. G. F.; CORTADA, C. N. M.; BARNABE, V. H.; DE CLERCQ, J. B. P.; BOLS, P. E. J. Roles of lipid peroxidation and cytoplasmic droplets on in vitro fertilization capacity of sperm collected from bovine epididymis stored at 4 and $34^{\circ} \mathrm{C}$. Theriogenology, Philadelphia, v. 67, n. 2, p. 334-340, 2007.

OLIVEIRA, C. H.; VASCONCELOS, A. B.; SOUZA, F. A.; MARTINS-FILHO, O. A.; SILVA, M. X.; VARAGO, F. C.; LAGARES, M. A. Cholesterol additions protect membrane intactness during cryopreservation of stallion sperm. Animal Reproduction Science, Amsterdam, v. 118, n. 2-4, p. 194-200, 2010.

PÉREZ-PÉ, R.; CEBRIÁN-PÉREZ, J. A.; MUIÑOBLANCO, T. Semen plasma proteins prevent cold-shock membrane damage to ram spermatozoa. Theriogenology, Philadelphia, v. 56, n. 3, p. 425-434, 2001.

PURDY, P. H.; GRAHAM, J. K. Effect of adding cholesterol to bull sperm membranes on sperm capacitation, the acrosome reaction, and fertility. Biology of Reproduction, New York, v. 71, n. 2, p. 522-527, 2004.

RICKER, J. V.; LINFOR, J. J.; DELFINO, W. J.; KYSAR, P.; SCHOLTZ, E. L.; TABLIN, F.; CROWE, J. H.; BALL, B. A.; MEYERS, S. A. Equine sperm membrane phase behavior: the effects of lipid-based cryoprotectants. Biology of Reproduction, New York, v. 74, n. 2, p. 359-365, 2006.

SALAZAR, J. L. J.; TEAGUE, S. R.; LOVE, C. C.; BRINSKO, S. P.; BLANCHARD, T. L.; VARNER, D. D. Effect of cryopreservation protocol on post thaw characteristics of stallion sperm. Theriogenology, Philadelphia, v. 76, n. 3, p. 409-418, 2011.

SAMPAIO, I. B. M.Estatística aplicada à experimentação animal. Belo Horizonte: Fundação de Ensino e Pesquisa em Medicina Veterinária, 1998. 221p.

STATISTICAL ANALYSIS SYSTEM INSTITUTE SAS. SAS/STAT software, Version 8. 02, Cary: 2001.
SIEME, H. Freezing semen. In: MCKINNON, A. O.; SQUIRES, E. L.; VAALA, W. E.; VARNER, D. D. (Ed.). Equine reproduction. 2. ed. Oxford: Wiley-Blackwell Publishing Ltd, 2011. cap. 315, p. 2972-2982.

SPIZZIRI, B. E.; BRUEMMER, J. E.; SQUIRES, E. L.; GRAHAM, J. K. Cholesterol-loaded-cyclodextrins and fertility potential of stallions spermatozoa. Animal Reproduction Science, Amsterdam, v. 118, n. 2-4, p. 255264, 2010.

TAKAHASHI, T.; ITOH, R.; NISHINOMIYA, H.; KATOH, M.; MANABE, N. Effect of linoleic acid albumin in a dilution solution and long-term equilibration for freezing of bovine spermatozoa with poor freezability. Reproduction in Domestic Animals, Berlin, v. 47, n. 1, p. 92-97, 2012.

TOWHIDI, A.; PARKS, J. E. Effect of n-3 fatty acids and $\alpha$-tocopherol on post-thaw parameters and fatty acid composition of bovine sperm. Journal of Assisted Reproduction and Genetics, New York, v. 29, n. 10, p. 1051-1056, 2012.

THUN, R.; HURTADO, M.; JANETT, F. Comparison of biociphos-plus and TRIS-egg yolk extender for cryopreservation of bull semen. Theriogenology, Philadelphia, v. 57, n. 3, p. 1087-1094, 2002.

WATSON, P. F. The causes of reduced fertility with cryopreserved semen. Animal Reproduction Science, Amsterdam, v. 60-61, p. 481-492, 2000.

YANAGIMACHI, R. Mammalian fertilization. In: KNOBILL, E.; NEIL, J. D. (Ed.). The physiology of reproduction. 2. ed. New York: Raven Press Ltd, 1994. cap. 5, p. 189-317.

ZAHN, F. S.; PAPA, F. O.; DELL'AQUA JÚNIOR, J. A. Cholesterol incorporation on equine sperm membrane: effects on post thaw sperm parameters and fertility. Theriogenology, Philadelphia, v. 58, n. 2-4, p. 237-240, 2002. 
